\title{
Assessing the Impacts of Stormwater Runoff from I-59 to a Headwater Stream in Central Alabama
}

\author{
Mitchell F. Moore, Catherine G. Butler and José G. Vasconcelos
}

Auburn University, Auburn, Alabama.

Received 201407 24, accepted 201411 26, published 20150206.

\begin{abstract}
Some studies have shown that stormwater runoff may have constituents that cause adverse impacts to aquatic ecosystems. Various related studies have focused either on characterizing the runoff directly generated on roads or on the effectiveness of various pollutant removal techniques. This work presents and discusses the results of an ongoing investigation on the impact of stormwater runoff from an interstate highway measured at a receiving stream. Water samples were collected at selected points and hydrological and water quality parameters were continuously monitored in selected stations. Quality parameters included nitrogen and phosphorus species, dissolved oxygen, total suspended solids and total solids, $\mathrm{pH}$, turbidity, specific conductivity and temperature. Ongoing work attempts to establish a relationship between highway traffic, time between rain events, rainfall depth and changes in water quality parameters in the stream as a result of road runoff. The purpose of this study is to quantify and assess road impacts on a small Alabama watershed and how it differs from impacts caused by other land uses in watersheds, and whether traffic and the proximity of an interstate highway are related to such impacts.
\end{abstract}

Keywords: stormwater, runoff, highways, pollutants, urbanization.

\section{Introduction}

Stormwater management can be viewed as a group of institutional, managerial and engineering approaches that aims to maintain the integrity and stability of receiving water bodies and ecosystems affected by stormwater runoff (U.S. Environmental Protection Agency 2005). In the context of Alabama's roads and the National Pollutant Discharge Elimination System (NPDES), the Alabama Department of Environmental Management (ADEM) recently issued MS4 permit coverage to the Alabama Department of Transportation (ALDOT) (ADEM 2013). The permit, AL000006, regulates stormwater discharges from ALDOT properties located within urban municipal boundaries. Among the elements and requirements of the permit is the need to implement controls to minimize the impacts of stormwater during and after construction. In order to attain the goals of post-construction stormwater management, considering that stormwater runoff impacts may also originate from other land uses in the watershed, it is essential to obtain pre-development information on the hydrological and water quality characteristics.

ALDOT's MS4 permit is relevant in the context of the Birmingham Northern Beltline, an ongoing 52 mile $(84 \mathrm{~km})$ road project carrying traffic around the north and west of Birmingham, Alabama. The proposed road alignment intersects a number of streams that are very important to the state such as the Cahaba and Black Warrior rivers.

One of the streams is the Little Cahaba Creek, a headwater perennial stream that is at the easternmost point of the Northern Beltline. The stream's watershed is also intersected by interstate highway 1-59. While baseline information for assessing any potential post-construction stormwater runoff impacts in Little Cahaba Creek is needed, the existence of I-59 provides also a chance to evaluate any long term post-construction impacts of I-59 into Little Cahaba Creek. This motivated the ongoing research presented here.

\subsection{Stormwater Runoff from Highways.}

Human activities in watersheds, such as construction and urbanization, will lead to impacts on land, streams and other environmental systems. Stormwater drainage is one important cause of environmental impacts, both hydrological (increases in peak flows and runoff volumes) and in constituents in stormwater. In this context, roadways are a source of short and long term impacts, though in stormwater management most focus is placed in short term impacts (Wheeler et al. 2006). Roadways and vehicular traffic are potential sources of various pollutants from tire wear, brake linings, oil leakage, pavement degradation and atmospheric deposition (Shaheen 1975; Han et al. 2006). However, if there is

Moore, M., C.G. Butler and J. Vasconcelos. 2015. "Assessing the Impacts of Stormwater Runoff from I-59 to a Headwater Stream in Central Alabama." Journal of Water Management Modeling C383. doi: 10.14796/JWMM.C383.

(c) CHI 2015 www.chijournal.org ISSN: 2292-6062 
development in the watersheds where roads are located, these other types of land use will also create impacts.

Paved roadway surfaces cause decreases in the pervious areas in watersheds, yet the area occupied by a given road can be relatively small, and thus mitigate this effect. With regards to water quality impacts, various constituents may be present in the runoff in roadways. The National Stormwater Quality Database (NQSD) version 1.1 (Pitt and Maestre 2005) compares runoff constituent concentrations for different land uses with data collected across the United States (200 MS4 systems). Compared to other land uses, runoff from roadways is a significant source of total suspended solids, oil and grease, chemical oxygen demand, organic nitrogen, ammonia, copper and petroleum hydrocarbons. Wu et al. (1998) determined that $20 \%$ of TSS loadings, $70 \%$ to $90 \%$ of nitrogen loadings, and between $10 \%$ and $50 \%$ of other constituents are sourced from atmospheric deposition. A summary of some of the data in the NSQD is presented in Table 1. Federal Highway Administration (FHWA)-sponsored research (Driscoll et al. 1990) presents summary data for a variety of stormwater roadway runoff related parameters from multiple states. The average values for parameters relevant to this study from this FHWA report includes: $143 \mathrm{mg} / \mathrm{L} \mathrm{TSS}, 432 \mathrm{mg} / \mathrm{L} \mathrm{TS}, \mathrm{pH} 6.5,103 \mathrm{mg} / \mathrm{L} \mathrm{COD}$, $0.84 \mathrm{mg} / \mathrm{L}$ nitrite, $1.79 \mathrm{mg} / \mathrm{L}$ total organic nitrogen, and $0.435 \mathrm{mg} / \mathrm{L}$ phosphate. In addition to this study, Schueler et al. (1992) determined that atmospheric deposition accounts for $70 \%$ to $95 \%$ of nitrogen and $20 \%$ to $35 \%$ of phosphorus in stormwater runoff, indicating that vehicular traffic is not the sole source of nutrient input in highway stormwater runoff.

Table 1 Summary of available data from the NSQD (Pitt and Maestre 2005) for mixed open space and mixed freeways; $\mathrm{Cv}$ is the coefficient of variation.

\begin{tabular}{clcc}
\hline Land Use & \multicolumn{1}{c}{ Parameter } & Median & $\mathrm{Cv}$ \\
\hline Mixed Open Space & $\mathrm{pH}$ & $7.9 \mathrm{units}$ & 0.08 \\
& Conductivity & $113 \mu \mathrm{S}$ & 0.5 \\
& $\mathrm{TSS}$ & $48.5 \mathrm{mg} / \mathrm{L}$ & 1.5 \\
& $\mathrm{NO}_{3}$ & $0.7 \mathrm{mg} / \mathrm{L}$ & 0.8 \\
& $\mathrm{NH}_{3}$ & $0.51 \mathrm{mg} / \mathrm{L}$ & 1.2 \\
& $\mathrm{TN}$ & $2.21 \mathrm{mg} / \mathrm{L}$ & - \\
& $\mathrm{TP}$ & $0.25 \mathrm{mg} / \mathrm{L}$ & 1.1 \\
\hline Mixed Freeway & $\mathrm{pH}$ & $7.7 \mathrm{units}$ & 0.1 \\
& $\mathrm{Conductivity}$ & $353 \mu \mathrm{S}$ & 0.6 \\
& $\mathrm{TSS}$ & $88 \mathrm{mg} / \mathrm{L}$ & 1.1 \\
& $\mathrm{NO}{ }_{3}$ & $0.9 \mathrm{mg} / \mathrm{L}$ & 0.7 \\
& $\mathrm{NH}_{3}$ & $1.07 \mathrm{mg} / \mathrm{L}$ & - \\
& $\mathrm{TN}$ & $3.2 \mathrm{mg} / \mathrm{L}$ & - \\
& $\mathrm{TP}$ & $0.34 \mathrm{mg} / \mathrm{L}$ & 0.7 \\
\hline
\end{tabular}

The impacts of these constituents on natural systems are site specific due to a high variability between measurements and the receiving water body characteristics. While some past studies have highlighted the impacts of roadway runoff to natural environments (Marsalek et al. 1999; Johnson et al. 2007), generalizations are not possible and field studies are necessary. In the context of streams, the impacts from road runoff will be combined with impacts from other land uses. Thus stream water quality changes caused by roadway runoff need to be accounted for by other potential sources of runoff.

The introduction of stormwater runoff into a receiving water body involves complex systems of seasonal climate change, flow variations and other interactions. The hydrology of a perennial stream or similar water body includes groundwater-surface water interactions, the intersection of various stream channels, evapotranspiration, and other nonlinear hydrologic functions. The stream water quality within such systems is further complicated by other processes indirectly linked to stormwater runoff such as riverbank erosion, topsoil removal, upstream land use variability, aquatic organism interactions, and more. Because of these complexities, it is important to determine the impacts of stormwater runoff within the receiving water body, and not at the edge of the roadway or within drainage structures.

In summary, the task of determining the impacts of a roadway on a stream is not trivial as a variety of data is necessary. This includes, among others, rainfall regime, soil and geomorphologic characteristics, runoff constituents, other types of land uses in the watershed, and vehicular traffic volume. As a result, generalizations are difficult and such evaluations are site specific.

\section{Objectives}

The main objective of this ongoing study is to study the hydrological and water quality impacts of I-59 on the Little Cahaba Creek, linking such impacts to vehicular traffic. The study includes field monitoring of nitrogen and phosphorus species, solids, dissolved oxygen, temperature and $\mathrm{pH}$ among other parameters. Hydrological parameters monitored include rainfall, stream flow and groundwater levels. The ultimate goal is to understand the potential impacts of the Birmingham Northern Beltline to other headwater streams that intersect this road. It is also an objective to characterize the hydrology and water quality of Little Cahaba Creek prior to the construction of the beltline in the watershed. This will help in the post-construction stormwater management related to the MS4, which will be implemented on that site in the construction of the beltline.

\section{Methodology}

The Little Cahaba Creek is formed in a watershed of about $7 \mathrm{mi}^{2}$ $\left(18 \mathrm{~km}^{2}\right)$, receiving runoff from mainly rural land with some minor residential development. Along the length of this watershed, interstate highway $1-59$ crosses the creek at various locations, thus contributing runoff to the creek. Figure 1 shows the Little Cahaba 
Creek watershed and I-59. The black arrow indicates the location of the specific site reported herein, in which the Little Cahaba Creek branch (with a drainage area of approximately 670 acres, $2.7 \mathrm{~km}^{2}$ ) crosses I-59. Two sites were selected for this study, one upstream and one downstream of the interstate, in order to provide an initial estimate of the impact the interstate has on the quality and amount of stormwater runoff in the creek. This specific watershed was selected because it is the proposed site of the intersection between the existing highway (I-59) and streams within the beltline corridor, which is currently at the early stages of construction. Data was gathered at a 2 week interval (nutrients, $\mathrm{pH}, \mathrm{TSS}$ and turbidity) to be used as a baseline for comparison to collected data related to runoff from future roadway construction and operation.

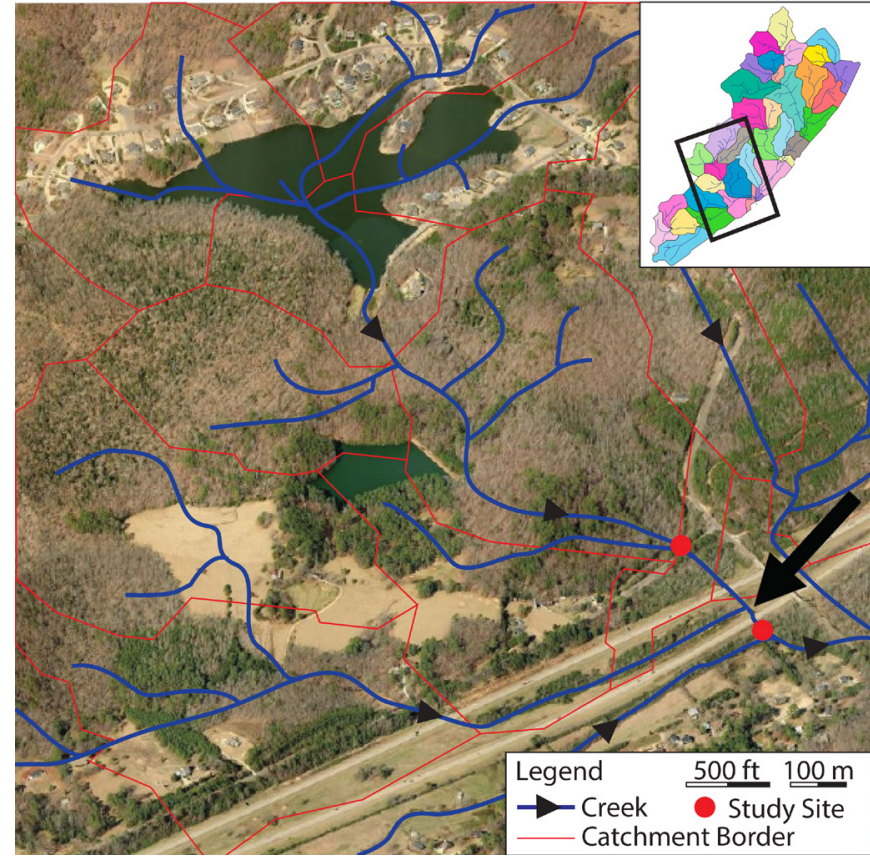

Figure 1 Little Cahaba Creek watershed along the interstate I-59 corridor (location of study site indicated by black arrow). Bird's eye view of the Little Cahaba Creek branch showing the location of the study sites (where sensors and instruments were placed and water samples were collected).

Little Cahaba Creek is a perennial stream, with a constant baseflow throughout the year in most of the stream network due to groundwater flows and upstream reservoirs. Soils in this watershed are primarily hydrological group B, gravelly silt loam (moderate $\mathrm{K}_{\text {sat' }}$ saturated conductivity), layered with fine grained clay layers (very low $\mathrm{K}_{\text {sat }}$ ). Because of this, there is a moderate amount of infiltration, yielding a relatively consistent groundwater influence on the watershed. Additionally, the soils are underlain by limestone, chert, and sandstone from the Knox Group, Sequatchie Formation and Chickamauga Limestone, and Red Mountain Formation. These units are adequate for conveying groundwater. There is faulting and folding in the region, which the length of
Little Cahaba Creek parallels on the southeast portion of the watershed. These geologic features have produced springs in the area that feed lakes and ponds, adding to the constant flow of water in the creek.

Various water quality parameters and hydrological parameters have been monitored during this study at selected sites in the watershed. The water quality parameters included in this study are total suspended sediments, total solids, turbidity, temperature, $\mathrm{pH}$, specific conductivity, dissolved oxygen, nitrate, nitrite, ammonia, total nitrogen, ortho- and poly-phosphate, and total phosphorus. The hydrological parameters included in this study are stream level, stream flow and velocity, and cross-sectional areas. Figure 1 shows the location of the two sites of this study. This stream flows from the northwest to the separated by I-59 which crosses the creek at several locations, and contributes runoff.

At the upstream site, water samples were collected, the cross section was surveyed and stream levels were measured within this rectangular concrete culvert at every visit to develop head-discharge curves. An environmental sonde and level loggers were also deployed at this station. The same general arrangement was also used at the site downstream from the I-59 crossing. Figure 2 shows the setup and location of equipment at the downstream site. The monitoring upstream aims to quantify the impacts of other land uses upstream from the interstate highway, namely open terrain and some residential development.

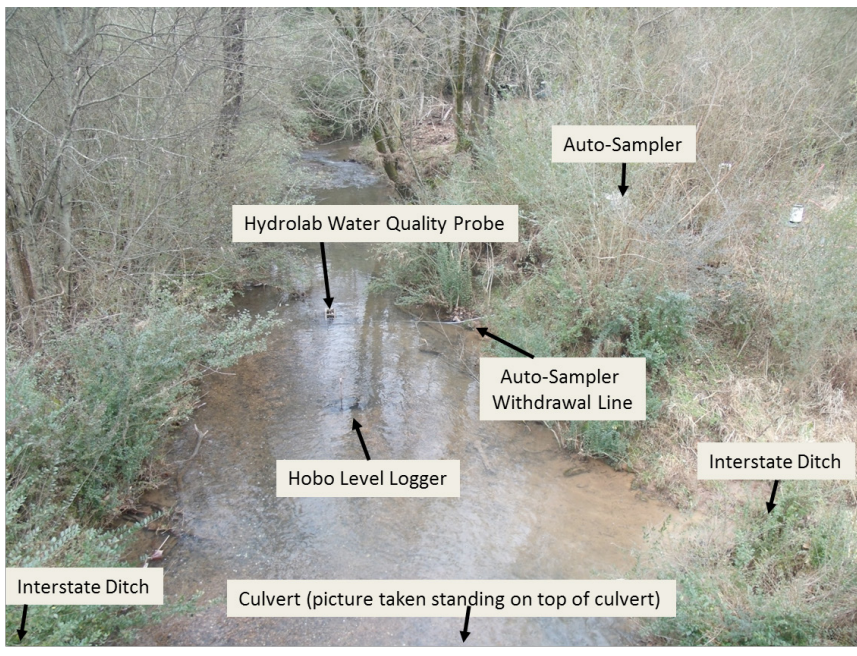

Figure 2 Downstream site monitoring equipment is identified by text boxes and arrows; for scale, the width of this stream is approximately $18 \mathrm{ft}(5.5 \mathrm{~m})$.

\subsection{Solids and Physical Property Monitoring}

Commonly measured parameters in water quality studies are total solids (TS) and total suspended sediments (TSS). These parameters are among the simplest and most cost effective measurements to quantify and qualify the impact of stormwater runoff. TS is defined as the amount (weight) of material in sampled water after all the water has been evaporated at a constant temper- 
ature (approximately $103^{\circ} \mathrm{F}, 39.4^{\circ} \mathrm{C}, \mathrm{SM} 2450 \mathrm{~B}$ ). TSS is defined as the amount of material remaining on a filter with a pore size of $1.2 \mu \mathrm{m}$ (SM 2540D). TSS is a fraction or portion of the TS. Turbidity is a parameter that is related to the amount of suspended particles in a water sample which reflect light that passes through the water. Thus it can be seen as a sort of cloudiness factor that can be correlated to the TSS and TS of the sample. Turbidity was measured, approximately every 2 weeks in the field and in the laboratory with a LaMotte turbidity meter, as well as continuously in the field by a Hydrolab probe. A calibrated Extech handheld $\mathrm{pH}$ meter and thermometer were also used to characterize these physical parameters in the streams.

TSS, TS and turbidity were sampled primarily in two ways during this research. First, at an interval of approximately 2 weeks, two grab samples (for repeatability) were collected from each of the sample sites for analysis following the procedures outlined in Pitt (2007). Duplicates for turbidity were measured, and if the readings varied by more than $5 \%$ to $10 \%$, it was considered an error of measurement (such as disturbing the underlying sediment during sampling), and the readings were repeated. Averaged values of these two readings are reported and used in the analysis. Additionally, $\mathrm{pH}$ and temperature were measured on site. Second, samples were collected by an ISCO 6100 series auto-sampler positioned at each site. These instruments are activated by rainfall readings (values are defined by the user, in this case 0.1 in., $2.54 \mathrm{~mm}$, every $15 \mathrm{~min}$ ) from an attached rain gauge. Once activated, the instrument pumps water from the stream through an attached hose line into a set of bottles within the auto-sampler. Samples of $800 \mathrm{~mL}$ were collected in these bottles at intervals of $15 \mathrm{~min}$. Thus with 24 bottles, $6 \mathrm{~h}$ of samples were collected in certain rain events. By defining the rainfall dependent start time as the same for each sampler, the same amount of rain at each site should activate the auto-samplers at the same time. Due to interception of rainfall and spatial differences in rainfall distribution, they did not always turn on at the same time. The samples were brought to a water quality laboratory at Auburn University where TS and TSS parameters were measured following the Standard Methods Procedures (SM 2540).

\subsection{Continuous Water Quality Monitoring}

In order to continuously monitor the water quality in Little Cahaba Creek, two Hydrolab DS5 environmental sondes were deployed at the upstream and downstream sites. At the downstream site, the sonde was deployed at a location that allows for the mixing of flows coming from roadside ditches and the median. At the upstream site the probe was placed $>30 \mathrm{~m}$ away from the interstate highway in order to minimize any effect from the road runoff in its measurements. Parameters at these two probes were continuously measured at 30 min intervals.

Every 2 weeks two newly calibrated probes were deployed replacing the previously deployed sensors to ensure the quality of the data. Calibration of these probes consists of adjusting the DO, turbidity, specific conductivity and $\mathrm{pH}$ sensors to a known value or regulated buffer solution. Table 2 shows the accuracy levels for each parameter measured by the probe. These probes were obtained and deployed about halfway through our sampling period to date (from August 2013), and thus do not represent a full year of monitoring.

Table 2 Sampling sensors and measurement accuracy for the Hydrolab Environmental sonde.

\begin{tabular}{lc}
\hline \multicolumn{1}{c}{ Hydrolab Sonde Parameters } & Accuracy \\
\hline Temperature Sensor & $\pm 0.10^{\circ} \mathrm{C}$ \\
Specific Conductance Sensor & $\pm 1 \%$ reading; $\pm 0.001 \mathrm{mS} / \mathrm{cm}$ \\
pH Sensor & \pm 0.2 units \\
Dissolved Oxygen (LD0) Sensor & $\pm 0.02 \mathrm{mg} / \mathrm{L}$ for $>8 \mathrm{mg} / \mathrm{L}$ \\
Self-cleaning Turbidity & $\pm 1 \%$ up to $100 \mathrm{NTU}$ \\
\hline
\end{tabular}

\subsection{Nitrogen and Phosphorus Species Measure- ments}

Nitrogen and phosphorus species were measured from the grab samples collected at our site every 2 weeks. Samples were collected, preserved, and tested with a Hach DR/890 colorimeter, for a full year from March 2013 to March 2014. The major nitrogen species include nitrate $\left(\mathrm{NO}_{3}\right)$, nitrite $\left(\mathrm{NO}_{2}\right)$, ammonia $\left(\mathrm{NH}_{3}\right)$ and organic nitrogen (TKN). This work measured nitrate, nitrite, ammonia, and total nitrogen using Hach methods 8192, 8507, 8155 and 10071 respectively. Thus, by subtracting the three nitrogen species measured from the total nitrogen measured in the lab, the organic nitrogen fraction can be determined. Phosphorus species consists of ortho-phosphate, poly-phosphate, and organic phosphate. Similar to our analysis of nitrogen, we measured orthoand poly-phosphate, as well as total phosphate in our laboratory, according to Hach methods 8048,8180 and 8190 respectively. By subtracting ortho- and poly-phosphate from the total phosphorus measured, the organic phosphorus can be determined.

In order to promote quality control of nutrient concentration measurements, the samples tested for nitrogen and phosphorus concentrations were analysed in an ion chromatograph (IC) column every month. The point collection data was tested with an IC column from Dionex Products. The first full run of water samples and standards showed an average error of $\sim 22 \%$. The IC column was run with standards with the following concentrations: $0.25 \mathrm{mg} \mathrm{NO}_{3^{\prime}}, 1.0 \mathrm{mg} / \mathrm{L} \mathrm{NO}_{3^{\prime}} 2.0 \mathrm{mg} / \mathrm{L} \mathrm{NO}_{3}$ and $0.5 \mathrm{mg} \mathrm{PO}_{4^{\prime}}$ $1.5 \mathrm{mg} / \mathrm{L} \mathrm{PO}_{4^{\prime}} 3.0 \mathrm{mg} / \mathrm{L} \mathrm{PO}_{4}$. All the standards had a $R^{2}$ coefficient in the range 0.9993 to 1.0 . As the investigation progressed, IC column and colorimeter results showed increased consistency.

\subsection{Hydrology Characterization}

Continual measurement of flow in a stream is often accomplished by the construction of a weir, using a pre-existing structure, or by integrating the velocity and area relationship of the stream. In order to reduce our impact of the stream we used the velocity-area approach. During the initial months of this study, and at both upstream and downstream sites, cross sections of the channel were surveyed at regular intervals. The water depth at each stream 
segment was measured along with water velocity using a Global Water current meter. Integration of the velocity and area over the width of the channel yields flow rate using equation 1 :

$$
Q=\sum_{i=1}^{n} A_{i} V_{i}
$$

where:

$$
\begin{aligned}
n & =\text { total number of cross section verticals, } \\
i & =\text { interval section, } \\
A & =\text { area, and } \\
V & =\text { velocity. }
\end{aligned}
$$

In addition to measurements within the channel, water height within the interstate culvert perched outlet yielded the critical depth discharge condition and a simple flow determination. Figure 3 shows the data points collected and curves are calculated with Equation 1.

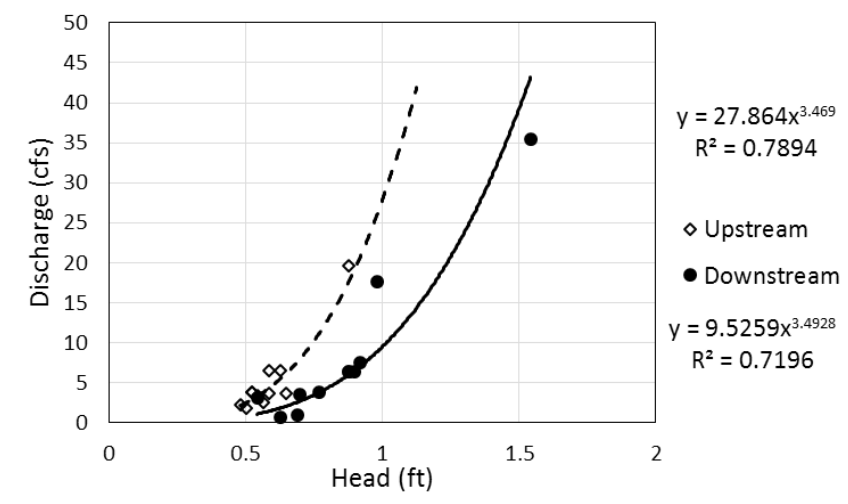

Figure 3 Head-discharge curve for upstream and downstream sites; the lines represent the fitted $\mathrm{H}-\mathrm{Q}$ equations.

These $\mathrm{H}-\mathrm{Q}$ curves were used with $\mathrm{HOBO}$ level loggers to determine flow rates with a 30 min interval ( $\pm 5 \%$ of reading). These loggers measured the pressure experienced by the sensor, which included both the water pressure and the changing atmospheric pressure. In order to compensate for atmospheric pressure, an additional pressure sensor was deployed nearby so that these atmospheric pressure changes could be discounted in the readings. In addition to the stream level measurements, two HOBO RG3 rain gauges were installed in the Little Cahaba Creek watershed.

\section{Results and Discussion}

\subsection{Traffic Data}

A continuous traffic meter (ATR-163) operated by ALDOT at a point 2 miles $(3.2 \mathrm{~km}$ ) from the research site provided a $1 \mathrm{~h}$ series of traffic flow during an entire week (Figure 4). Measurements from 3 months were used to derive an average traffic and standard deviations for the traffic at each hour. This in turn was used as a means to estimate the vehicle count between consecutive rainfall events. This vehicle count was compared to the water quality parameter turbidity results taken for upstream and downstream of the interstate, as is shown below.

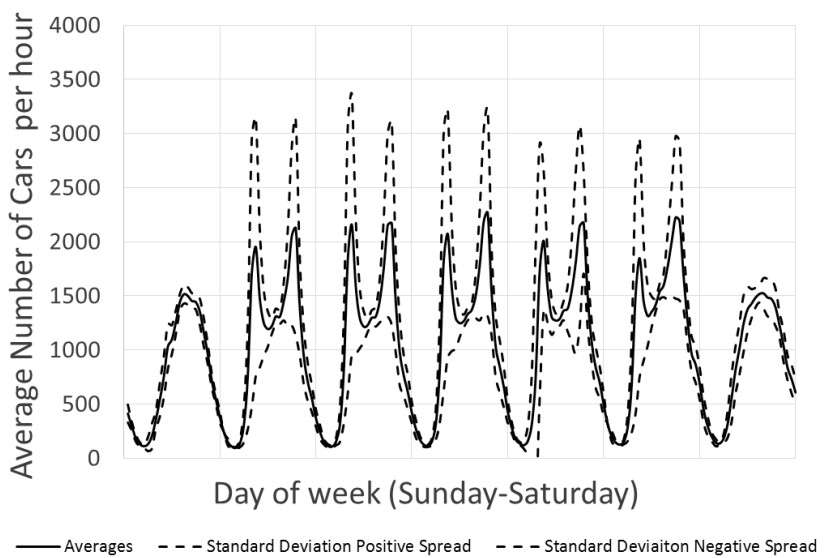

Figure 4 Average daily traffic over 1 week on I-59 north of Birmingham, Alabama mile post 140.2.

The number of hours between rain events was compared to the level of turbidity. This relationship yielded a decaying trend, while the relationship of turbidity and the traffic amount between rain events showed no correlation between the two. In order to improve the relationship between turbidity and time or turbidity and the traffic amount, the $x$-axis was multiplied by the total rainfall depth per rain event raised to the power of 1.5. By mulitiplying the turbidity by the total rainfall depth, Figures 5 and 6 are able to represent the storm size and intensity. The exponent 1.5 yielded the best relationships between turbidity and time and turbidity and traffic. Further nonlinear regression efforts will still be attempted to improve the relationships between these variables.

Another action was taken to improve the quality and correlation between these variables. At times the upstream sonde data consistently reported higher base levels of turbidity than the downstream location. This difference in the base levels of turbidity could be attributed to the deployment of the upstream sonde, which could cause sediments to accumulate near the sensor interfering with turbidity values. In order to account for this error in deployment, the level of turbidity upstream was reduced by the difference in the initial turbidity level downstream and upstream. The relationships between turbidity and time and traffic are show in Figures 5 and 6 . More data points will be included over time to assess more accurately the relationships between turbidity, hours between rain events, rainfall depth and vehicular traffic. 


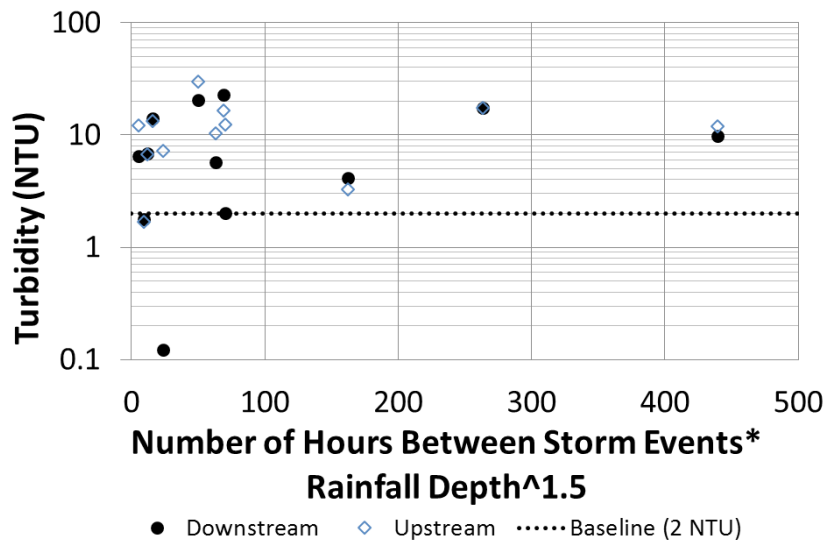

Figure 5 Average turbidity compared to the number of hours between rain events multiplied by the rainfall depth (in.) $\wedge 1.5$ (Cambez et al. 2008).

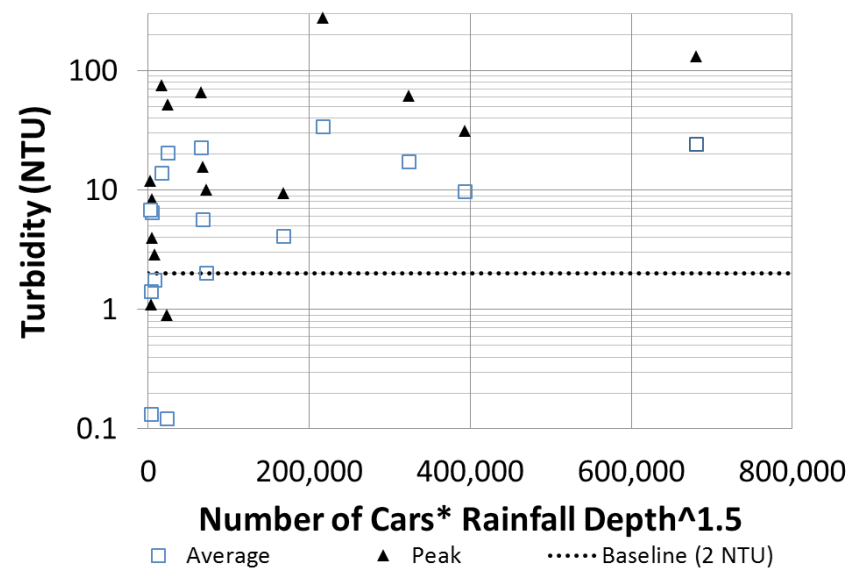

Figure 6 Turbidity compared to the number of cars between rain events multiplied by the rainfall depth (in.) $\wedge 1.5$.

\subsection{TSS and Turbidity Measurements}

Rainfall events sampled with the auto-samplers in three dates are presented in this work: 201310 07, 20131101 and 20140221. In all of these events there is a good correlation between the rain intensity and the increased amount of turbidity and TSS due to the increase in stream flow and runoff. The increase of TSS and turbidity in the upstream site was generally minor, but the impact at the upstream station was much more pronounced. This is currently being investigated as the source for this could either be the road runoff itself or another catchment that contributes to LCC between the upstream and the downstream site.

TSS, turbidity and rainfall measurements for both upstream and downstream sites are shown in Figures 7 to 9. In all of these events, the TSS and Turbidity at the upstream site have not exceeded $7.2 \mathrm{mg} / \mathrm{L}$ and 3.6 NTU, respectively, whereas the downstream location reached values of $500 \mathrm{mg} / \mathrm{L}$ and 110.8 NTU. The event on 20140221 represents a more typical relationship between TSS and turbidity, where the TSS and turbidity upstream samples are on the same scale of magnitude as the downstream samples. The delay between the rain event start and the peak of the TSS/turbidity at the downstream station varied between $1.5 \mathrm{~h}$ and $3 \mathrm{~h}$.

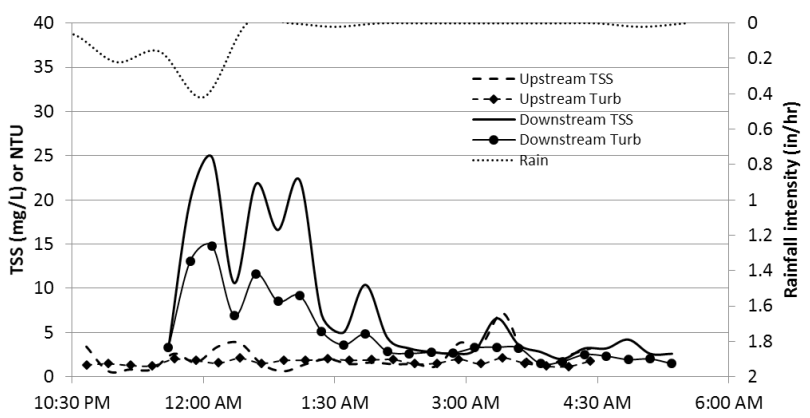

Figure 7 TSS and turbidity measurements for a rain event on 20131006.

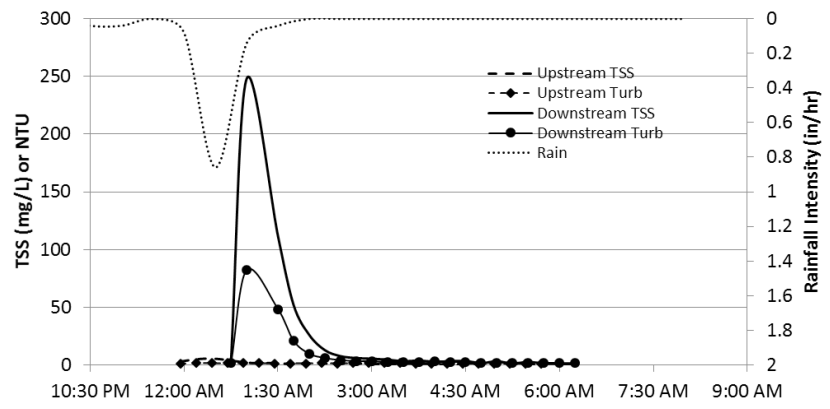

Figure 8 TSS and turbidity measurements for a rain event on 20131101.

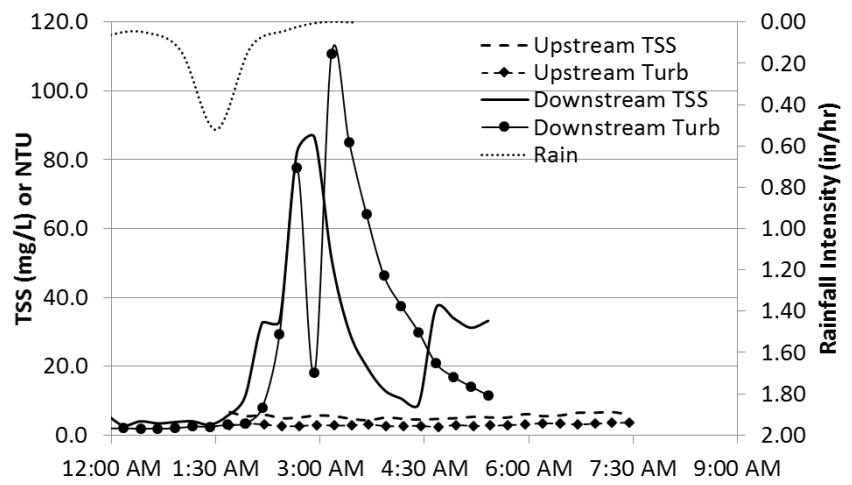

Figure 9 TSS and turbidity measurements for a rain event on 20140221.

Figure 10 shows the overall correlation between TSS and turbidity. This relationship was derived from the TSS and turbidity results found in the Auburn University laboratory by taking all the points from the adequate auto-sampler sets as well as the stream samples. There is significant scatter in the TSS and turbidity 
relation for the range of TSS between $1 \mathrm{mg} / \mathrm{L}$ and $8 \mathrm{mg} / \mathrm{L}$, though this scatter decreases outside this range. Most TSS and turbidity results at the upstream site were under $32 \mathrm{mg} / \mathrm{L}$ and $16 \mathrm{NTU}$ respectively. Results for the downstream site, however, could exceed $64 \mathrm{mg} / \mathrm{L}$ TSS and $>32$ NTU during rain events. As mentioned earlier, this could be caused by the median and ditches runoff or by another LCC tributary that merges with the stream between the upstream and downstream sites.
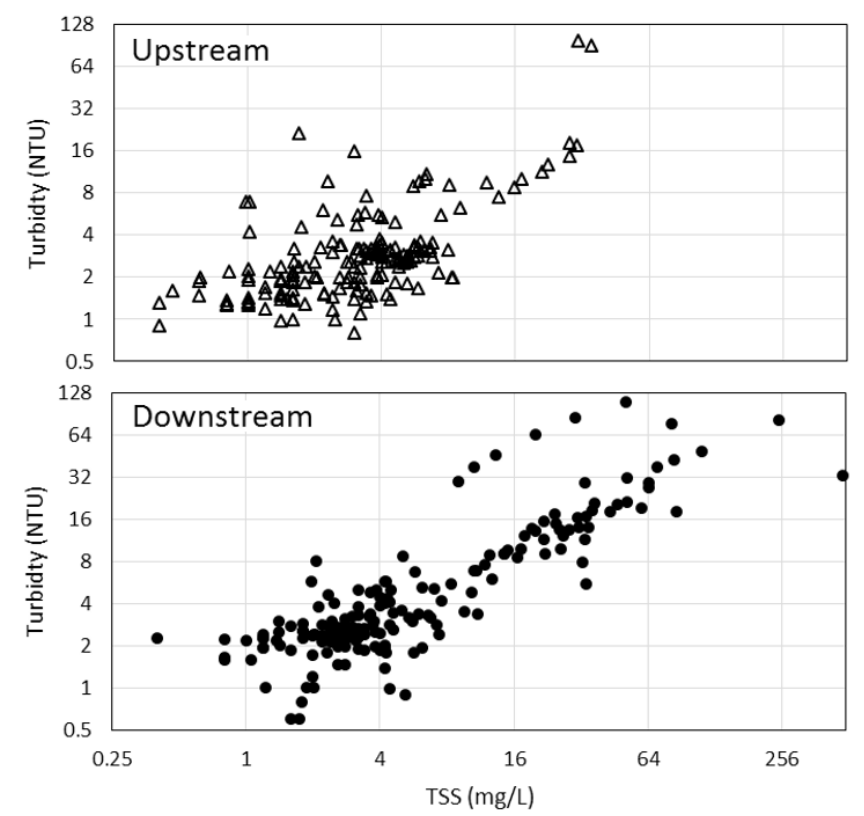

Figure 10 Turbidity vs TSS measurements for both sections of the stream (note the significant difference in scale for the TSS between sites).

For the physical parameters in the point sample collections, TS tended to be greater more than $72 \mathrm{~h}$ after a rain event. TSS upstream of the interstate tended to be greater within the $72 \mathrm{~h}$ following a rain event while the TSS downstream of the interstate highway tended to be greater after $72 \mathrm{~h}$ following the rain event. The average turbidity across all sites tended to be greater for the samples collected within $72 \mathrm{~h}$ of a rain event. Table 3 summarizes some statistical data from the upstream and downstream sites for these parameters.

Table 3 Summary of available sediment statistical data for the upstream (site 3) and downstream (site 1) sites.

\begin{tabular}{cccccccc}
\hline & & \multicolumn{4}{c}{$\begin{array}{c}\text { Occurred within } 72 \mathrm{~h} \text { of } \\
\text { a rain event }\end{array}$} & \multicolumn{2}{c}{$\begin{array}{c}\text { Occurred }>72 \mathrm{~h} \text { after a } \\
\text { rain event }\end{array}$} \\
$\begin{array}{c}\text { Physical } \\
\text { Parameter }\end{array}$ & Site & Avge & Std Dev $\boldsymbol{\sigma}$ & Avge & Std Dev $\boldsymbol{\sigma}$ & Avge & Std Dev $\boldsymbol{\sigma}$ \\
\hline TS (mg/L) & 1 & 118.808 & 32.585 & 111.071 & 36.642 & 127.833 & 24.141 \\
& 3 & 116.577 & 32.783 & 112.857 & 38.645 & 120.917 & 23.479 \\
TSS (mg/L) & 1 & 3.188 & 9.990 & 2.071 & 11.781 & 4.492 & 7.152 \\
& 3 & 12.558 & 26.369 & 16.807 & 34.904 & 7.600 & 6.293 \\
Turb (NTU) & 1 & 3.769 & 2.843 & 4.327 & 3.318 & 2.989 & 1.714 \\
& 3 & 3.398 & 3.195 & 3.717 & 3.447 & 2.953 & 2.744 \\
\hline
\end{tabular}

\subsection{Results of Nitrogen and Phosphorus Species}

\section{Measurements}

Figures 11 to 14 are a comparison of the upstream and downstream nutrient levels: nitrate $\left(\mathrm{NO}_{3}\right)$, ammonia-nitrogen $\left(\mathrm{NH}_{3}-\mathrm{N}\right)$, total nitrogen (TN), and total phosphorus (TP), respectively. These figures represent measurements over 12 months, with estimated detection limits (EDT) and the degree of accuracy for each Hach test measurement represented in the figure caption.

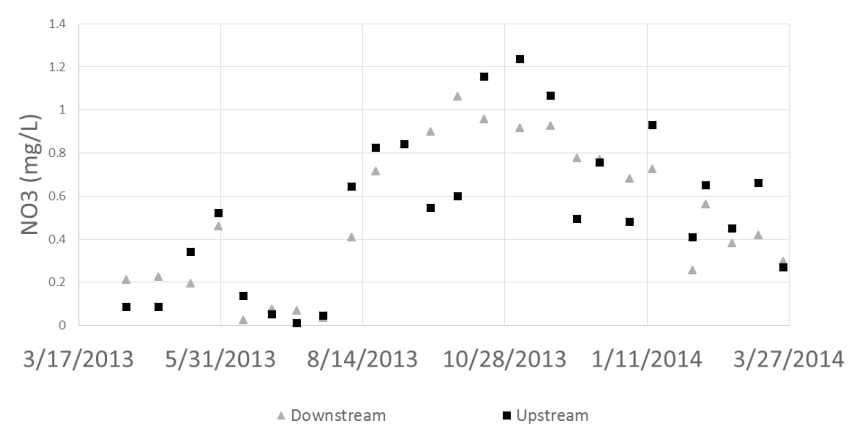

Figure 11 Upstream and downstream sites $\mathrm{NO}_{3}$ results expressed as N (EDT: 0.01 ppm $\mathrm{NO}_{3}-\mathrm{N}$; accuracy: $\pm 0.03 \mathrm{mg} / \mathrm{L})$.

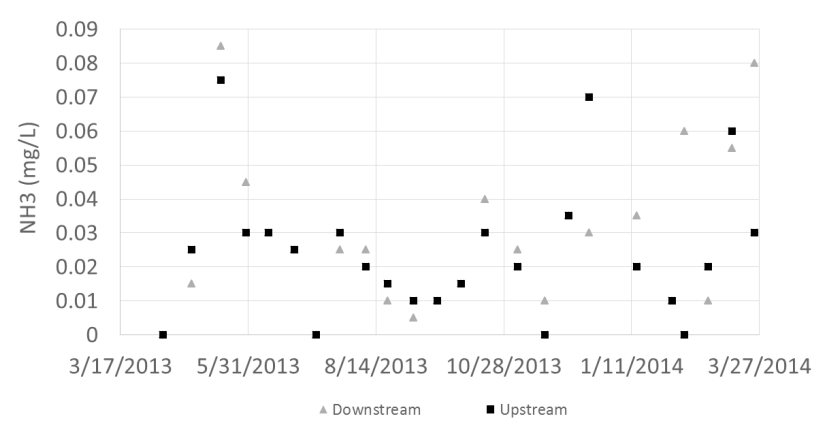

Figure 12 Upstream and downstream sites $\mathrm{NH}_{3}-\mathrm{N}$ results expressed as $\mathrm{N}$ (EDT: $0.07 \mathrm{ppm} \mathrm{N}$; accuracy: $\pm 0.02 \mathrm{mg} / \mathrm{L})$.

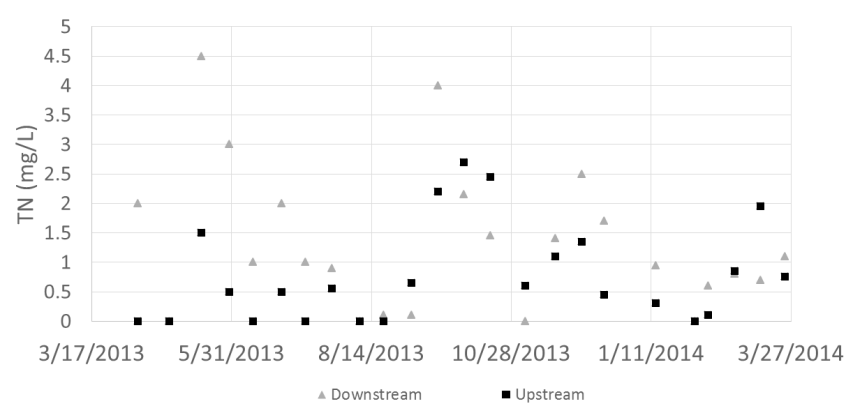

Figure 13 Upstream and downstream sites total nitrogen results (EDT: 2 ppm N; accuracy: $\pm 0.05 \mathrm{mg} / \mathrm{L}$ ). 


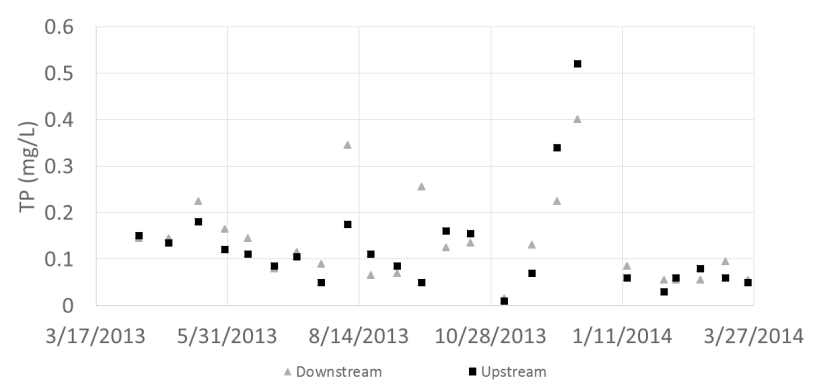

Figure 14 Upstream and downstream sites total phosphorus results (EDT: 0.07 ppm $\mathrm{PO}_{4}$; accuracy: $\pm 0.07 \mathrm{mg} / \mathrm{L}$ ).

$\mathrm{TN}, \mathrm{TP}$ and $\mathrm{NH}_{3}$ all show no major seasonal variations. The level of $\mathrm{NO}_{3}$ rose from August to January by approximately $1 \mathrm{ppm}$. The collected data also indicates that overall there is no significant increase of nutrients between the upstream and downstream stations across the interstate highway. The downstream station, however, tended to have higher levels of TN than the upstream station. This increase in TN could be caused by atmospheric deposition in the paved area, or by vehicular exhaust. Since vehicle exhaust contains nitrogen oxides, such as NO and $\mathrm{NO}_{2}$, and $\mathrm{NH}_{3}$ (AQEG 2004), vehicle exhaust may be a contributing factor to this increase in nitrogen (Capea et al. 2004). If this increase in nitrogen is caused by vehicular exhaust, plant growth and development near the interstate highway may increase with increased traffic of the BNB highway (Capea et al. 2004). Other than TN, nutrient levels were generally low and often below the detection limits of the methods used in this study.

Over the collection period of point samples, the overall average and standard deviation was taken for each of the seven nitrogen and phosphorus species: $\mathrm{NO}_{3^{\prime}}, \mathrm{TN}, \mathrm{NH}_{3^{\prime}} \mathrm{NO}_{2}-\mathrm{N}, \mathrm{TP}$, $\mathrm{PO}_{4}{ }^{3-}$ and poly-phosphate. Average and standard deviation were calculated for the all samples by grouping results with different methods. The collection points taken within $72 \mathrm{~h}$ of a rain event were separated from the samples that were collected after those $72 \mathrm{~h}$ following a rain event. In addition, results from all samples were characterized in terms of average and standard deviation, irrespective of how recent the rain evens were.

In general all samples contain relatively small concentrations of $\mathrm{N}$ and $\mathrm{P}$ species, and the values are consistent with the National Stormwater Quality Database version 1.1 (Pitt and Maestre 2005). For nitrogen species, results from all sites were in general larger for samples taken after $72 \mathrm{~h}$ following a rain event. Site 2 and site 4 had comparatively larger values of $\mathrm{NH}_{3}$ and $\mathrm{NO}_{3}$ in the period after the $72 \mathrm{~h}$ after a rain event; however, both of these sites are downstream of farmland.

For phosphorus species, the upstream and downstream sites were found to have greater values on average within $72 \mathrm{~h}$ of a rain event. Many possible factors can contribute to this presence of phosphorus species during rain events such as weathering phosphorus materials in streambeds or organic or inorganic material from nearby land. Table 4 summarizes the available statistical data for the nutrients discussed herein.
Table 4 Summary of available nutrient statistical data for the upstream (site 3) and downstream (site 1) sites.

\begin{tabular}{|c|c|c|c|c|c|c|c|c|c|}
\hline \multirow[b]{2}{*}{ Nutrient } & \multirow[b]{2}{*}{ Site } & \multicolumn{8}{|c|}{ 0ccurred within 720 ccurred $72 \mathrm{~h}$ after } \\
\hline & & $\begin{array}{c}\text { Avge } \\
(\mathrm{mg} / \mathrm{L})\end{array}$ & $\begin{array}{c}\text { Std Dev } \sigma \\
(\mathrm{mg} / \mathrm{L})\end{array}$ & $\begin{array}{l}\text { Avge } \\
\text { (mg/L) }\end{array}$ & $\begin{array}{c}\text { Std Dev } \sigma \\
(\mathrm{mg} / \mathrm{L})\end{array}$ & $\begin{array}{l}\text { Avge } \\
(\mathrm{mg} / \mathrm{L})\end{array}$ & $\begin{array}{c}\text { Std Dev } \sigma \\
(\mathrm{mg} / \mathrm{L})\end{array}$ & $\begin{array}{c}\text { Err } \pm \\
(\mathrm{mg} / \mathrm{L})\end{array}$ & $\begin{array}{l}\text { Detn } \\
\text { Limit } \\
\text { (mg/L) }\end{array}$ \\
\hline \multirow[t]{2}{*}{ N03 } & 1 & 0.499 & 0.327 & 0.450 & 0.314 & 0.556 & 0.333 & 0.03 & 0.01 \\
\hline & 3 & 0.528 & 0.350 & 0.506 & 0.348 & 0.552 & 0.351 & & \\
\hline \multirow[t]{2}{*}{ TN } & 1 & 1.312 & 1.187 & 0.927 & 0.778 & 1.729 & 1.394 & 0.5 & 2 \\
\hline & 3 & 0.794 & 0.805 & 0.521 & 0.691 & 1.067 & 0.819 & & \\
\hline \multirow[t]{2}{*}{ NH3 } & 1 & 0.032 & 0.029 & 0.035 & 0.028 & 0.028 & 0.029 & 0.02 & 0.02 \\
\hline & 3 & 0.026 & 0.021 & 0.030 & 0.018 & 0.023 & 0.023 & & \\
\hline \multirow[t]{2}{*}{ NO2-N } & 1 & 0.006 & 0.008 & 0.003 & 0.003 & 0.010 & 0.010 & 0.003 & 0.005 \\
\hline & 3 & 0.007 & 0.008 & 0.003 & 0.003 & 0.012 & 0.010 & & \\
\hline \multirow[t]{2}{*}{ TP } & 1 & 0.218 & 0.296 & 0.308 & 0.384 & 0.121 & 0.067 & 0.06 & 0.07 \\
\hline & 3 & 0.162 & 0.199 & 0.249 & 0.258 & 0.082 & 0.041 & & \\
\hline \multirow[t]{2}{*}{$\mathrm{PO}_{4}^{3-}$} & 1 & 0.583 & 0.474 & 0.770 & 0.565 & 0.379 & 0.208 & 0.05 & 0.05 \\
\hline & 3 & 0.484 & 0.445 & 0.522 & 0.545 & 0.443 & 0.295 & & \\
\hline \multirow[t]{2}{*}{ Poly-phos } & 1 & 0.499 & 0.303 & 0.490 & 0.330 & 0.510 & 0.269 & 0.05 & 0.05 \\
\hline & 3 & 0.445 & 0.337 & 0.458 & 0.296 & 0.431 & 0.376 & & \\
\hline
\end{tabular}

\subsection{Environmental Sonde Results}

The continuous measurement of DO, specific conductivity, $\mathrm{pH}$ and turbidity has provided insights into other impacts on Little Cahaba Creek from I-59. Figure 15 shows the variation of some parameters for a rain event on 201308 04. Since Alabama has a warmer climate, and salt is generally not used for de-icing roads, runoff from the interstate highway should not show significant conductivity levels. This data shows that runoff from I-59 displays low and insignificant conductivity levels.

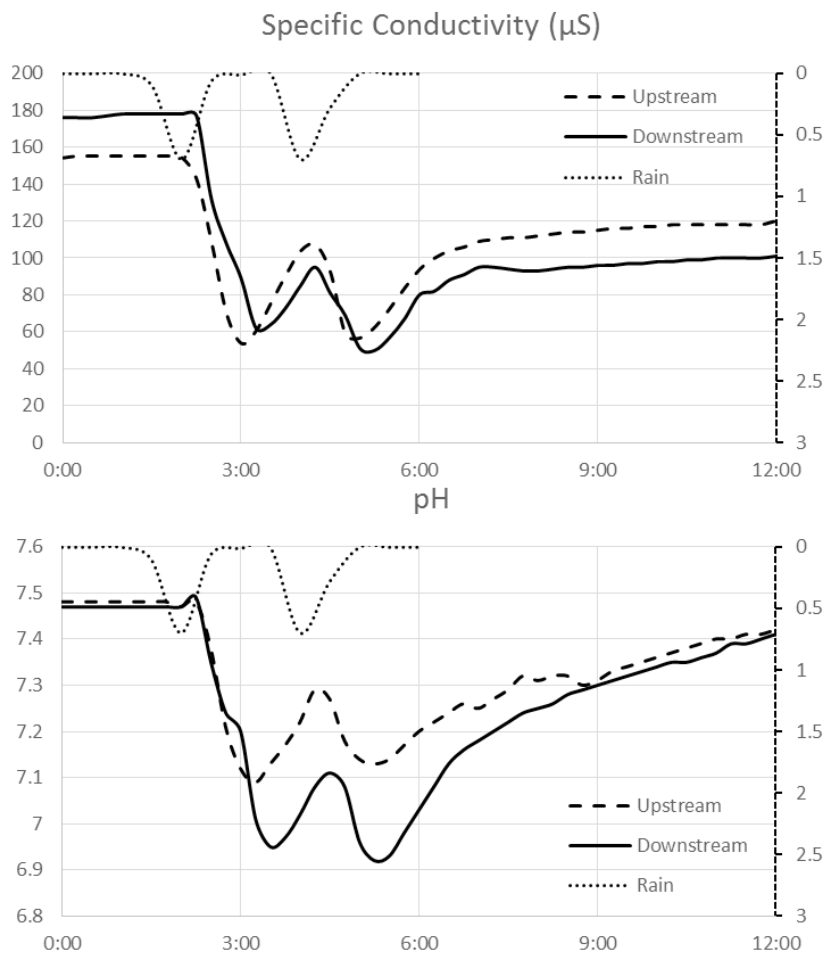

Figure 15 Stream responses measured on 20130804 by the sondes in Little Cahaba Creek. 
The values of three parameters were observed to change across I-59 during rain events: $\mathrm{pH}$, dissolved oxygen and turbidity. The $\mathrm{pH}$ results generally show a decrease during rainfall, which is result of the lower $\mathrm{pH}$ of rainfall (4.7 to 5) as reported by the National Atmospheric Deposition Program (National Atmospheric Deposition Program, NRSP-3 2014). However, the pH decreases significantly more downstream than upstream from the interstate highway. The $\mathrm{pH}$ decreases approximately 0.4 before the highway and an additional 0.1 across it. Dissolved oxygen generally increases across the highway during rain events, which is likely due to increased air entrainment in the perched outlet discharge during rain events. Specific conductivity decreases $40 \mu \mathrm{S}$ to $60 \mu \mathrm{S}$ during rain events, but does not significantly vary across I-59.

\subsection{Hydrology Results}

Average rainfall in the Birmingham area varies between 3 in. and 6 in. $(7.62 \mathrm{~cm}$ and $15.24 \mathrm{~cm})$ per month, with typical lows in the summer (NOAA 2002). Generally, there is little difference between the two rain gauges' rainfall measurements, though they are approximately 2.2 miles ( $3.5 \mathrm{~km}$ ) away from each other. Accordingly, data from the nearest rain gauge $(<0.5$ miles, $0.80 \mathrm{~km}$, from the stream-interstate highway crossing) is shown in Figure 16 for the past year of study. During this year, average rain events with intensities of approximately $0.5 \mathrm{in} . / \mathrm{h}(1.27 \mathrm{~cm} / \mathrm{h})$ occurred throughout the year, with infrequent rain event activity in the late summer and fall (late August to October). The most intense rain events (up to $\sim 2 \mathrm{in} . / \mathrm{h}, 5.08 \mathrm{~cm} / \mathrm{h}$ ) occur in the early summer months (June and July). These are not unusual rain events, as the $1 \mathrm{y}$ return period for $60 \mathrm{~min}$ duration rainfall produces approximately $1.5 \mathrm{in} . / \mathrm{h}(3.81 \mathrm{~cm} / \mathrm{h})$ intensity rains for this area (Perica et al. 2013).

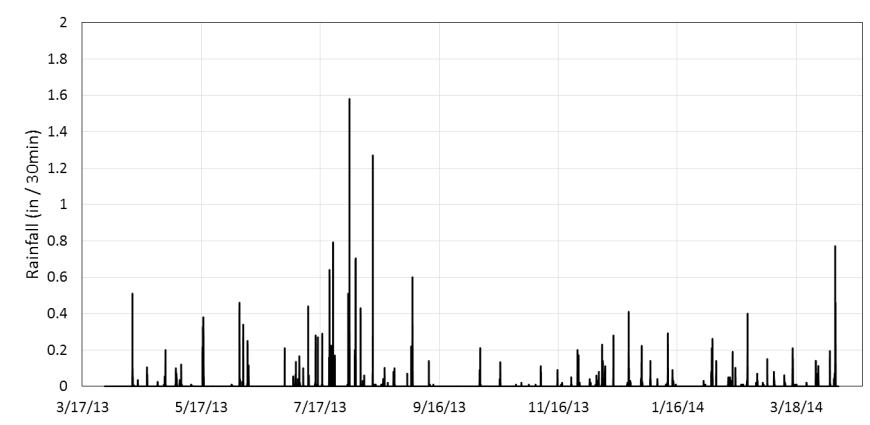

Figure 16 Rainfall series measured within the Little Cahaba Creek watershed, near the I-59 crossing.

Throughout most of the year, Little Cahaba Creek has base flows around $5 \mathrm{ft}^{3} / \mathrm{s}$ to $8 \mathrm{ft}^{3} / \mathrm{s}$ ( $141 \mathrm{~L} / \mathrm{s}$ to $226 \mathrm{~L} / \mathrm{s}$ ). The downstream portion of the creek typically has a base flow increment of $2 \mathrm{ft}^{3} / \mathrm{s}$ to $3 \mathrm{ft}^{3} / \mathrm{s}(56.6 \mathrm{~L} / \mathrm{s}$ to $85 \mathrm{~L} / \mathrm{s})$ compared to the upstream portion due to the intersection of another small tributary of the creek that drains a $\sim 150$ acre $\left(0.6 \mathrm{~km}^{2}\right)$ portion (rural area) of this watershed. Although there are many rain events in this area of Alabama (Figure 16), the stream does not always show significant responses to them, as presented in Figure 17. Abstraction and infiltration in the in the forested portion of the catchment decrease runoff volume, particularly during the warmer season when the rain events have relatively long antecedent dry periods and low intensities.

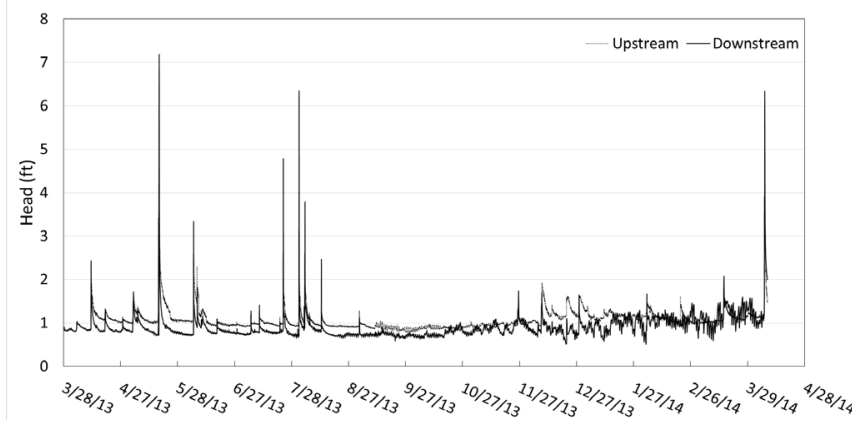

Figure 17 Stream stage height of Little Cahaba Creek upstream and downstream of I-59.

Figure 18 presents flows for a rain event on 20130710 derived with the $\mathrm{H}-\mathrm{Q}$ curve. This event is representative of a typical rain event and stream flow response during a rain event, where the base flow before the event is represented by a dashed line. A few other rain events in 2013 had relatively larger rainfall depths, and the stream responded with rises in stream levels of $>5 \mathrm{ft}$ $(1.5 \mathrm{~m})$. At these events, the developed head-discharge curve is invalid, because measurements were performed at lower flows.

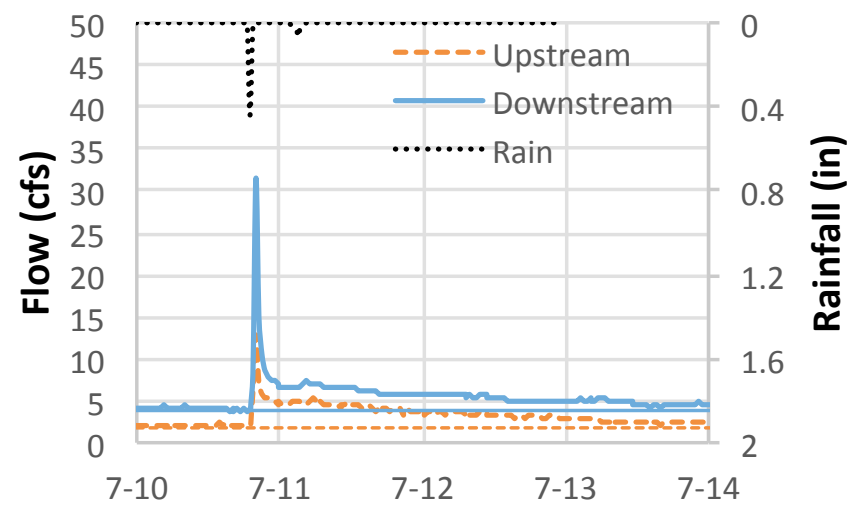

Figure 18 Calculated flow of Little Cahaba Creek upstream and downstream of the interstate on 201307 10; the event had 0.59 in. $(1.5 \mathrm{~cm})$ rain.

The stream flow definitely increases as it receives additional runoff while crossing the interstate. A relevant question is How much of this runoff is caused by increased imperviousness of the interstate and its associated structures as compared with natural preconstruction contributions? Also, Is this increased runoff proportional to the increased catchment area?

\subsection{Volumetric Runoff Coefficient Calculations}

Calculations of the volumetric runoff coefficient for selected events were conducted to obtain insights into the effect of the road on the flows measured in the stream. A constant base flow (the minimum value prior to the rain event) was removed from 
the volume calculations. Integration of the stream flow rate $(Q)$ over time yields the volume of water linked to the rain event as runoff (assuming that groundwater flows are moving much more gradually through the watershed). The volume of rainfall was determined by multiplying the rainfall depth for each event by the area of the contributing watershed. The subcatchment area is different for the upstream and downstream portions; the area contributing to the upstream portion of the stream is about 670 acres $\left(2.7 \mathrm{~km}^{2}\right)$, whereas the downstream portion of the stream has an additional 150 acres $\left(0.61 \mathrm{~km}^{2}\right)$ contributing to the runoff. At each time interval, the volumetric runoff coefficient was determined as the volume of runoff divided by the volume of rainfall for each station. Figures 19 and 20 show results of these calculations, including the change in the runoff coefficient over time.

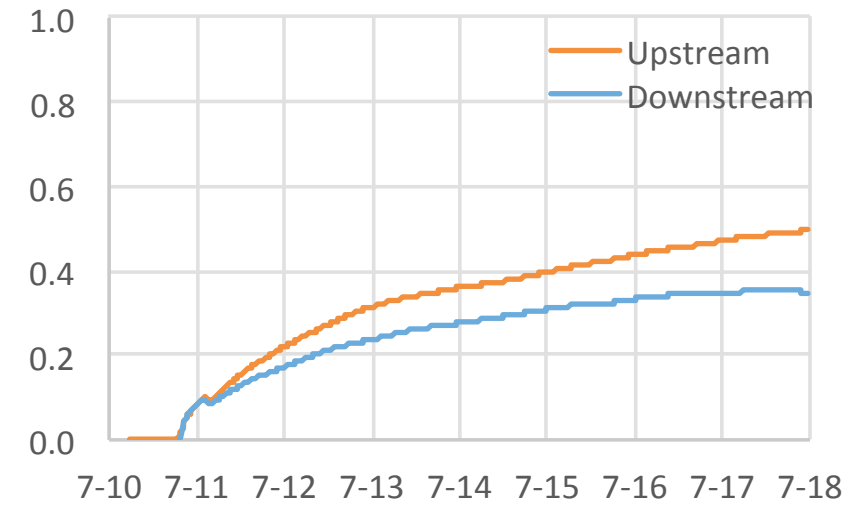

Figure 19 Volumetric runoff coefficient variation for a rain event on 20130710 (1.5 cm rain).

In the initial stages of the rain event there is a rapid increase in the runoff coefficient as more areas of the watershed contribute runoff at both upstream and downstream sites. Gradually the runoff coefficient begins to approach values in the range 0.16 to 0.36 for the downstream site and 0.25 to 0.50 for the upstream site. Considering the paved area of the interstate, such a result is at first counterintuitive as it would be expected that the increased imperviousness from the roadway surfaces would increase the runoff coefficient, not decrease it.

Two factors may have a role in reducing the volumetric runoff coefficient across the interstate highway in the presented cases. First, the tributary of the creek that joins the stream between the upstream and downstream sites drains a farmland area with the potential for large abstractions, which would decrease runoff contributions from that portion of the watershed. There is also potential for significant infiltration in the flat region at the I-59 median, also decreasing the fraction of overland flow. In addition, a good portion of the highway right of way is vegetated with trees covering streams, particularly in summer time. Further observations will be conducted on the site to confirm these results, including shallow groundwater wells.

Another interesting observation is that there are significant differences between the observed runoff coefficients from the two selected rain events. There are many variables that may yield different runoff coefficients between major rain event events. A key parameter pointed to by earlier studies (Hoffman et al. 1984; Irish et al. 1995) is the antecedent dry period. Longer dry periods are typically associated with higher values of initial abstractions and infiltration, which would significantly reduce runoff volumes. Another key parameter is antecedent moisture conditions, which is associated with the antecedent dry period. For the event shown in Figure 19, 201307 10, there were $3 \mathrm{~d}$ to $4 \mathrm{~d}$ since the last rain event. The event on Figure 20, 201308 20, had $\sim 8 d$ since the previous rain event. This difference may impact the volumetric runoff coefficient values for these two events.
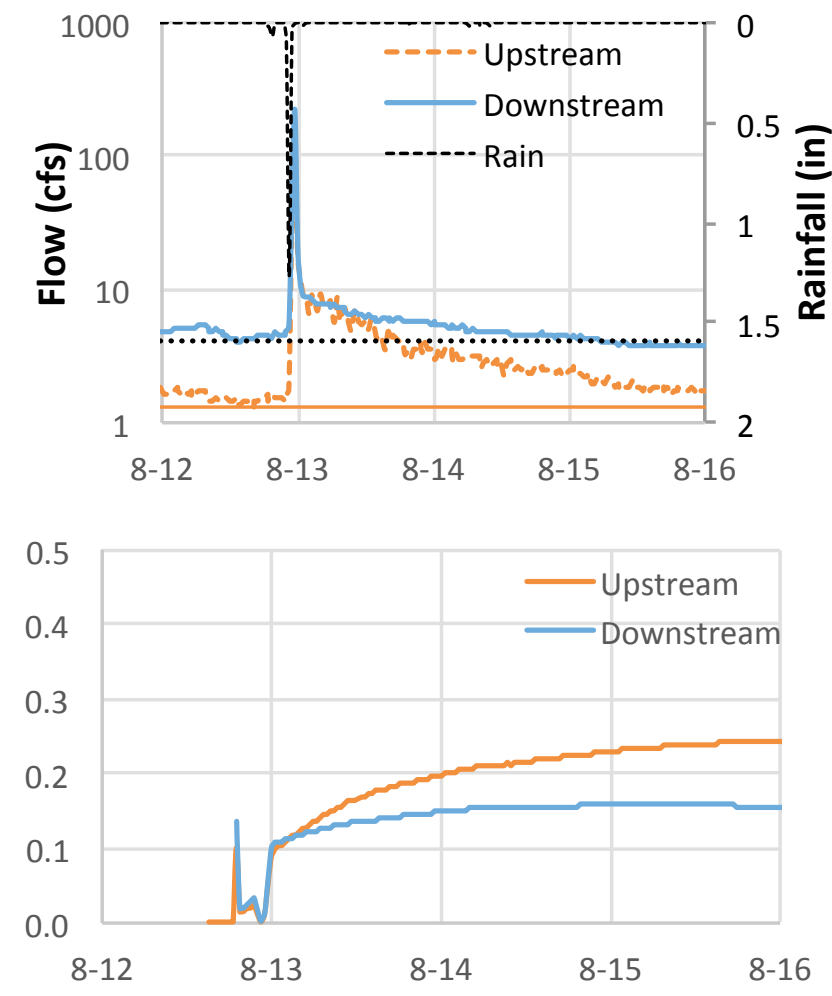

Figure 20 Hyetograph, stream flow and volumetric runoff coefficient variation for rain event on 201308 12; this event had a total rainfall of $1.51 \mathrm{in.}(3.84 \mathrm{~cm})$.

\section{Final Remarks}

Past investigations have shown that runoff from roads may include increased levels of nutrients and suspended solids among other constituents, as well as having impacts on the local hydrology of streams. This ongoing study focuses on measuring such impacts to Little Cahaba Creek at a point where it is crossed by 1-59. Development of the local watershed is limited, with residential areas, farmland and forested areas. Since the majority of runoff is conveyed as overland flow, with little to no hard-piping, abstractions and water quality are relatively higher than in more urban watersheds. As runoff from other land uses may also cause impact to streams, all characterization has been performed 
at a site upstream from the road, and another site immediately downstream from the interstate crossing.

While there are significantly larger values for the turbidity and TSS parameters at the downstream site during rain events, there has been seen no significant relationship in nitrogen and phosphorus species. The exception is total nitrogen values, which were larger, possibly due to organic nitrogen. Rain events have also caused a drop in specific conductivity and in $\mathrm{pH}$, but this effect was noticed in both sites across the interstate highway.

Additionally, based on volumetric runoff coefficient calculations, this coefficient has a lower value downstream from the roadway when compared to the upstream region. This result is somewhat counter-intuitive, considering the increase in imperviousness caused by paved surfaces. It is speculated that increased infiltration due to flatter slopes associated with the interstate highway ditches and medians has effectively reduced runoff values. It is important to highlight that these runoff coefficient results are still preliminary and further data collection and analysis will still be necessary to confirm the findings on runoff coefficients. Future measurements of the groundwater level response to rain events should help in determining whether this hypothesis is valid.

Future tasks related to this investigation will include: deployment of area-velocity sensors to determine flow rates during large rain events;

- analysis of the nutrient concentration during the first flush of a single rain event;

- synthesizing data from groundwater wells in this study site, which have been recently installed, to help understand the groundwater-surface water relationships;

- biological evaluations (macroinvertebrate evaluations) of the stormwater impacts to the LCC;

- water quality characterization from samples collected at the interstate highway median; and developing a SWMM model of the watershed and the role of the interstate's interaction with the creek, including groundwater contributions.

\section{Acknowledgments}

We acknowledge the Alabama Department of Transportation for funding this research as a part of the project number $930837 \mathrm{R}$, as well as ALDOT staff who have contributed towards the completion of our goals.

\section{References}

ADEM (Alabama Department of Environmental Management). 2013. MS4 Stormwater Management Program Plan: NPDES Permit No. ALS000006. Montgomery, AL: ADEM. https://www.dot.state.al.us/dsweb/Stormwater/doc/MS4SWMPP.pdf
AQEG (Air Quality Expert Group). 2004. Nitrogen Dioxide in the United Kingdom. London: Department for Environment, Food and Rural Affairs.

http://uk-air.defra.gov.uk/assets/documents/reports/aqeg/ nd-summary.pdf

Cambez, M. J., J. Pinho and L. M. David. 2008. “Using SWMM5 in the Continuous Modelling of Stormwater Hydraulics and Quality." Prepared for The 11th International Conference on Urban Drainage, Edinburgh, Scotland.

http://web.sbe.hw.ac.uk/staffprofiles/bdgsa/11th_International_Conference_on_Urban_Drainage_CD/ICUD08/ help.html.

Capea, J. N., Y. S. Tanga, N. van Dijka, L. Lovea, M. A. Suttona, and S. C. F. Palmer. 2004. "Concentrations of Ammonia and Nitrogen Dioxide at Roadside Verges, and their Contribution to Nitrogen Deposition." Environmental Pollution 132 (3): 469-78.

Driscoll, E. D., P. E. Shelly and E. W. Strecker. 1990. Pollutant Loadings and Impacts from Highway Stormwater Runoff, Volume 3: Analytical Investigation and Research Report. Federal Highway Administration Final Report FHWA-RD-88-008. McLean, VA: Federal Highway Administration. http://webdmamrl.er.usgs.gov/g1/FHWA/90Model/FHWARD-88-008.pdf

Han, Y., S. Lau, M. Kayhanian and M. K. Stenstrom. 2006. "Characteristics of Highway Stormwater Runoff." Water Environment Research 78 (12): 2377-88.

Hoffman, E. J., G. L. Mills, J. S. Latimer and J. G. Quinn. 1984. “Urban Runoff as a Source of Polycyclic Aromatic Hydrocarbons to Coastal Waters." Environmental Science and Technology 18:580-7.

Irish, L. B., Jr., W. G. Lesso, M. E. Barrett, J .F. Malina Jr, R. J. Charbeneau and G. H. Ward. 1995. An Evaluation of the Factors Affecting the Quality of Highway Runoff in the Austin, Texas Area. Technical Report CRWR 264. Austin, TX: University of Texas at Austin, Center for Research in Water Resources. http://www.crwr.utexas.edu/reports/pdf/1995/rpt95-9.pdf

Johnson, M. L., I. Werner, P. G. Green, S. Fong, L. Deanovic and C. C. Fessler. 2007. Toxicity of Stormwater from Transportation Facilities. Prepared for The Department of Transportation. Davis, CA: University of California, Davis.

Marsalek, J., Q. Rochfort, B. Brownlee, T. Mayer and M. Servos. 1999. “An Exploratory Study of Urban Runoff Toxicity." Water Science Technology 39 (12): 33-9.

National Atmospheric Deposition Program (NRSP-3). 2014. Illinois State Water Survey. Champaign, IL: NADP Program Office.

NOAA (National Oceanic and Atmospheric Administration). 2002, Climatography of the United States, No. 81: Monthly Station Normals of Temperature, Precipitation, and Heating and Cooling Degree Days 1971-2000. Asheville, NC: National Oceanic and Atmospheric Administration; National Environmental Satellite, Data, and Information Service; National Climatic 
Data Center.

http://nsstc.uah.edu/aosc/files/ALnorm.pdf

Perica, S., D. Martin, S. Pavlovic, I. Roy, M. St. Laurent, C. Trypaluk, D. Unruh, M. Yekta and G. Bonnin. 2013. NOAA Atlas 14:

Precipitation-Frequency Atlas of the United States. Vol. 9 Version 2.0: Southeastern States (Alabama, Arkansas, Florida, Georgia, Louisiana, Mississippi). Silver Spring, MD: U.S. Department of Commerce, National Oceanic and Atmospheric Administration, National Weather Service.

http://www.nws.noaa.gov/oh/hdsc/PF_documents/

Atlas14_Volume9.pdf.

Pitt, R. 2007. Water Sample Collection Methods. Module 3 of Experimental Design and Field Sampling. Tuscaloosa, AL: University of Alabama Department of Civil, Construction, and Environmental Engineering.

http://rpitt.eng.ua.edu/Class/Classes.shtml

Pitt, R. and A. Maestre. 2005. "The National Stormwater Quality Database (NSQD, version 1.1)." 1st Annual Stormwater Management Research Symposium Proceedings. Orlando, FL: University of Central Florida Stormwater Management Academy.

http://www.stormwater.ucf.edu/conferences/workshops/ symposiums/Proceedings\%202004.pdf

Schueler, T. R., P. A. Kumble and M. A. Heraty. 1992. Current Assessment of Urban Best Management Practices: Techniques for Reducing Non-Point Source Pollution in the Coastal Zone. Washington, DC: Metropolitan Washington Council of
Governments, Department of Environmental Programs, Anacostia Restoration Team.

Shaheen, D. G. 1975. Contributions of Urban Roadways to Water Pollution. Washington, DC: U. S. Environmental Protection Agency Office of Research and Development. EPA-600/275-004.

U.S. Environmental Protection Agency. 2005. Stormwater Phase 2 Final Rule: Small MS4 Stormwater Program Overview. Fact Sheet 2.0 (revised December 2005). Washington, DC: U. S. Environmental Protection Agency Office of Water. EPA 833F-00-002.

http://water.epa.gov/polwaste/npdes/stormwater/upload/ fact2-0.pdf

Wheeler, A. P., P. L. Angermeier and A. E. Rosenberger. 2006. "Impacts of New Highways and Subsequent Landscape Urbanization on Stream Habitat and Biota." Reviews in Fisheries Science 13 (3): 141-64.

Wu, J. S., C. J. Allan, W. L. Saunders and J. B. Evett. 1998. “Characterization and Pollutant Loading Estimation for Highway Runoff." Journal of Environmental Engineering 124:584-92. 